\title{
DNA from mollusc shell: a valuable and underutilised substrate for genetic analyses
}

\author{
Sara Ferreira $^{1}$, Rachael Ashby ${ }^{2}$, Gert-Jan Jeunen ${ }^{1}$, Kim Rutherford $^{1}$, Catherine Collins $^{1}$, Erica V Todd $^{1}$, Neil J \\ Gemmell ${ }^{\text {Corresp. } 1}$ \\ 1 Department of Anatomy, University of Otago, Dunedin, New Zealand \\ 2 Invermay Agricultural Centre, AgResearch, Dunedin, New Zealand \\ Corresponding Author: Neil J Gemmell \\ Email address: neil.gemmell@otago.ac.nz
}

Mollusc shells are an abundant resource that have been long used to predict the structures of ancient ecological communities, examine evolutionary processes, reconstruct paleoenvironmental conditions, track and predict responses to climatic change, and explore the movement of hominids across the globe. Despite the ubiquity of mollusc shell in many environments, it remains relatively unexplored as a substrate for molecular genetic analysis. Here we undertook a series of experiments using the New Zealand endemic greenshell mussel, Perna canaliculus, to explore the utility of fresh, aged, beachcast and cooked mollusc shell for molecular genetic analyses. We find that reasonable quantities of DNA (0.002-21.48 ng/mg shell) can be derived from aged, beach-cast and cooked mussel shell and that this can routinely provide enough material to undertake PCR analyses of mitochondrial and nuclear gene fragments. Mitochondrial PCR amplification had an average success rate of $96.5 \%$ from shell tissue extracted thirteen months after the animal's death. A success rate of $93.75 \%$ was obtained for cooked shells. Amplification of nuclear DNA (chitin synthase gene) was less successful (80\% success from fresh shells, decreasing to $10 \%$ with time, and $75 \%$ from cooked shells). Our results demonstrate the promise of mollusc shell as a substrate for genetic analyses targeting both mitochondrial and nuclear genes. 


\section{DNA from mollusc shell: a valuable and underutilised substrate for}

\section{2 genetic analyses}

3

4 Sara Ferreira ${ }^{1}$, Rachael Ashby ${ }^{2}$, Gert-Jan Jeunen ${ }^{1}$, Kim Rutherford ${ }^{1}$, Catherine Collins ${ }^{1}$, Erica V.

5 Todd $^{1}$, and Neil J. Gemmell ${ }^{1 *}$

$7 \quad{ }^{1}$ Department of Anatomy, University of Otago, Dunedin, New Zealand

82 Invermay Agricultural Centre, AgResearch, Dunedin, New Zealand

$10{ }^{*}$ Corresponding Author:

11 Neil J. Gemmell. Academic address: Department of Anatomy, 270 Great King Street, 12 Dunedin 9016, Otago, New Zealand.

14 Email address: neil.gemmell@otago.ac.nz

Abstract

17 Mollusc shells are an abundant resource that have been long used to predict the 18 structures of ancient ecological communities, examine evolutionary processes, 19 reconstruct paleoenvironmental conditions, track and predict responses to climatic 20 change, and explore the movement of hominids across the globe. Despite the ubiquity 21 of mollusc shell in many environments, it remains relatively unexplored as a substrate for 22 molecular genetic analysis. Here we undertook a series of experiments using the New 23 Zealand endemic greenshell mussel, Perna canaliculus, to explore the utility of fresh, 24 aged, beach-cast and cooked mollusc shell for molecular genetic analyses. We find that 
25 reasonable quantities of DNA $(0.002-21.48 \mathrm{ng} / \mathrm{mg}$ shell) can be derived from aged,

26 beach-cast and cooked mussel shell and that this can routinely provide enough material

27 to undertake PCR analyses of mitochondrial and nuclear gene fragments. Mitochondrial

28 PCR amplification had an average success rate of $96.5 \%$ from shell tissue extracted

29 thirteen months after the animal's death. A success rate of $93.75 \%$ was obtained for

30 cooked shells. Amplification of nuclear DNA (chitin synthase gene) was less successful

31 (80\% success from fresh shells, decreasing to $10 \%$ with time, and $75 \%$ from cooked

32 shells). Our results demonstrate the promise of mollusc shell as a substrate for genetic

33 analyses targeting both mitochondrial and nuclear genes.

\section{Introduction}

36 Molluscs are the most diverse of the marine phyla, with some 85,000 described species

37 (Chapman, 2009) that include animals such as clams, slugs and octopuses (Appeltans et

38 al., 2012). The characteristic mollusc shell, common to much of the phylum, consists

39 mainly of calcium-carbonate (Furuhashi et al., 2009), is highly resilient, and can persist

40 in the environment long after the animal has died (Vendrasco et al., 2016). In fossil

41 assemblages, for instance, shell material can be a predictor of ancient community

42 composition (Kidwell, 2001), and harbour a rich source of information for exploring

43 mollusc evolution (Vendrasco et al., 2016, Der Sarkissian et al., 2017, Coutellec, 2017)

44 and undertaking paleoenvironmental reconstructions (Rhoads, 1970, Krantz et al., 1987,

45 Coutellec, 2017, Der Sarkissian et al., 2017). Likewise, the almost ubiquitous exploitation

46 of marine mollusc as a coastal food source in many early human communities provides

47 a rich source of information on the lives of those people and the ecology and climate in

48 which they lived (Balbo et al., 2011, Barsh and Murphy, 2008, Colonese et al., 2011). 
49 Whether from natural samples or from samples collected and used by humans, analysis

50 of mollusc shell remains provide important insights into our past. The application of

51 techniques such as radiocarbon dating and the recently developed Amino Acid

52 Racemization (AAR) technique (Demarchi et al., 2011) give samples of mollusc shell

53 chronological meaning, while stable isotope analysis enables quantification of nutrient

54 flows and may provide some insights into food web dynamics (Zanden and Rasmussen,

55 2001). Finally, taxonomic analysis of mollusc shell remains provides knowledge of

56 species abundance and community structure, and when coupled with accurate

57 chronology can lead to significant insights into how species, communities and

58 ecosystems respond to a variety of anthropogenic pressures and environmental changes

59 (Balbo et al., 2011, Estevez et al., 2001).

60 Species identification based on shell valves often relies on specialised taxonomic 61 knowledge, a scientific skill in continuous decline since the 1950's (Tautz et al., 2003,

62 Hebert and Gregory, 2005, Kim and Byrne, 2006). Unlike DNA from soft tissues, which

63 degrades relatively quickly following the death of the organism, DNA molecules

64 incorporated within mineral matrix such as bone and teeth is largely protected from

65 enzymatic and microbial degradation (Pääbo et al., 2004, Higgins et al., 2015). The

66 development of techniques that enabled the extraction of trace amounts of DNA from

67 ancient mineralizeu ussue samples such as bone and teeth (Kalmár et al., 2000, Höss

68 and Pääbo, 1993, Rohland and Hofreiter, 2007) sparked interest in whether other

69 mineralized tissues, such as mollusc shell, might also have utility for DNA analyses

70 f(Doherty et al., 2007, Barsh and Murphy, 2008, Geist et al., 2008, Wang et al., 2012, Der

71 Sarkissian et al., 2017).

72 In bivalves, a group of specialised hematocyte cells called refractive granulocytes has

73 been shown to be involved in the secretion, and active remodelling of calcium carbonate

74 crystals for the formation of the shell (Mount et al., 2004, Li et al., 2016, Ivanina et al., 
75 2017). It is likely that during this process, these cells might be trapped and absorbed in

76 the growing shell, leaving traces of DNA (Doherty et al., 2007, Wang et al., 2012, Barsh

77 and Murphy, 2008, Der Sarkissian et al., 2017). These DNA traces provide an opportunity

78 to genetically analyse recently dead individuals, historical specimens, samples from shell

79 middens and even ancient shell samples (Der Sarkissian et al., 2017).

80 Moreover, because living molluscs can quickly repair shell damage (Fleury et al., 2008),

81 shell sampling techniques that avoid damaging the underlying mantle epithelia enable

82 non-lethal sampling of valuable animals, such as aquaculture broodstock or those of

83 endangered species (Wang et al., 2012).

84 Despite its broad appeal, the use of mollusc shell as a source of DNA for molecular 85 analysis remains incipient. Here we undertook a series of experiments, using shell 86 remains from the widespread and commercially important bivalve mollusc, the New

87 Zealand greenshell mussel (Perna canaliculus (Gmelin 1791ł), to develop an effective 88 and reliable method for extracting genomic DNA from mollusc shells. We test the effects

89 of shell age and treatment (e.g., cooking and weathering) on DNA quality and suitability 90 for downstream analysis by PCR using mitochondrial and nuclear primers.

91

\section{Materials \& Methods}

93 For all experiments, live greenshell mussels were acquired from commercial sources in

94 Dunedin, New Zealand. Animals were completely removed from their shells, which were 95 then cleaned with at least three rinses of distilled water before being dried in an incubator 96 at $20^{\circ} \mathrm{C}$ overnight. One of the valves was subsequently roughly smashed and a $0.5 \mathrm{~g}$ viull 97 sample taken for DNA extraction. 
99

100

101

102 103

104 105

Ageing shells: For each of 10 individuals, shell samples were taken from the same valve at monthly intervals over 13 months (130 samples in total). DNA extraction was performed immediately after each collection. During the sampling period, shells were individually wrapped in foil and stored at room temperature in a plastic bag to ensure minimal airflow.

Cooked mussel shells: Sixteen live whole greenshell mussels were divided into four treatment groups, and cooked either by steaming in salted water or cooking over firewood embers, two common ways to cook shellfish, for either five or ten minutes (four mussels per treatment). Shells of cooked mussels were thoroughly cleaned to remove soft tissue, before being rinsed and dried as described above. After drying, large amounts of the periostracum - the outermost layer of the shell - peeled off, particularly around the edges. Shell samples were collected from each animal and immediately processed for DNA extraction.

Beach-cast shells: Eleven shells (single valves) of $P$. canaliculus were collected from two beach locations (Dunedin, New Zealand), cleaned and dried as described previously. For each valve there was an attempt to collect samples from 1) the outermost ventral part of the shell; 2) within the area of the pallial sinus, and 3) the umbo of each shell, which would include ligament tissue if present (Fig. 1). Some valves were found broken, and did not allow sampling of all three areas. Given the low DNA yield expected for such shells, we assessed the potential risk of cross-contamination of mussel DNA within our laboratory. An additional sample was collected from 8 of the beach- cast shell valves and used for DNA extraction and amplification in a different research facility (different lab in another building of the University of Otago, Dunedin campus) following the extraction and amplification methods described here, so that the risk of contamination in our own facility 
124 could be assessed. Once collected, samples were processed for DNA extraction 125 immediately after collection.

126

127 DNA extraction method: Shell samples were broken into smaller pieces in a mortar and 128 pestle, re-weighed, and placed in a SafeLock $2 \mathrm{~mL}$ tube (Eppendorf) with a stainless steel $1295 \mathrm{~mm}$ bead (Qiagen). All samples and two blank tubes (steal bead but no shell) were 130 processed using a TissueLyser II machine (Qiagen) at the maximum frequency setting $131(30 \mathrm{~Hz})$ for five minutes. DNA was extracted following a salting-out method (Gemmell and 132 Akayama, 1996), with these modifications: 1) lysis incubation was performed overnight; 133 2) the resulting DNA was resuspended in $100, \bar{N}$ ow EDTA TE buffer $(10 \mathrm{mM}$ Tris- $\mathrm{HCl}$, 134 0.1 mM EDTA, pH 8). DNA yields were determined using a Qubit ${ }^{\circledR} 2.0$ Fluorometer 135 (ThermoFisher Scientific), using the dsDNA HS Assay (ThermoFisher Scientific). DNA 136 (ng)/shell ( $r_{1, y}$, sample ratios were calculated for each sample. Shell valves from beach137 stranded specimens were very brittle, and were processed solely with mortar and pestle. DNA from these samples was eluted in $40 \mu \mathrm{L}$ low EDTA TE buffer.

139

140 DNA quality assessment by PCR - mtDNA: We designed a set of two mitochondrial 141 DNA (mtDNA) PCR primers to produce amplicons in the range of $<200$ to 300 base pairs 142 (bp) (Table 1) using Primer3Plus (Untergasser et al., 2012), under the expectation that 143 DNA extracted from bivalve shell material would be degraded and of low yield (Taberlet 144 et al., 1999). Primers were designed using published sequences from the work of Blair et 145 al. (2006), with the exception of one primer which was originally designed by these same 146 authors (Blair et al., 2006) (primer COX1 Fwd, see Table 1). Targeted mitochondrial 147 regions were the COX1 gene (primers COX1 Fwd and COX1 Rev, specific to Perna spp.) 148 and the NADH4/ ATP8 gene region (primers Pcan Fwd and Pcan Rev, specific to $P$. 149 canaliculus alone) (Table 1). PCR reactions were carried out in a total volume of $30 \mu \mathrm{L}$, 
150 containing 1x Bioline $\mathrm{NH}_{4}$ Reaction Buffer, 0.1U Bioline BIOTAQ ${ }^{\mathrm{TM}}$ DNA Polymerase,

$1512.75 \mathrm{mM} \mathrm{MgCl}_{2}$ solution, $0.25 \mu \mathrm{M}$ of each primer, $0.25 \mu \mathrm{M}$ dNTP's and $1.5 \mu \mathrm{L}$ DNA. Bovine

152 Serum Albumin (BSA) was also added at a concentration of $10 \mathrm{mM}$ BSA in the PCR using

153 Pcan primers-, and $40 \mathrm{mM}$ in the COX1 PCR. Reactions were run in an MJ Research

154 Tetrad PTC-225 Thermal Cycler.

155 The PCR program for mtDNA primers was 1 minute at $96^{\circ} \mathrm{C}$, followed by 35 cycles of 1

156 minute at $96^{\circ} \mathrm{C}, 30 \mathrm{sec}$ at $57^{\circ} \mathrm{C}$ and $30 \mathrm{sec}$ at $72^{\circ} \mathrm{C}$, with a final elongation step of 5

157 minutes at $72^{\circ} \mathrm{C}$. Positive and negative (no template) controls were always included. The

158 positive control was a 1:100 dilution of DNA $(1.5 \mathrm{ng} / \mu \mathrm{L})$ extracted from fresh mantle tissue

159 of one individual sacrificed for the ageing shell experiment, using the DNA extraction

160 method described by (Gemmell and Akayama, 1996). PCR product (20 $\mu \mathrm{L})$ was

161 visualised through a 1.5\% agarose gel stained with $1 \times$ GelRed (Biotum), together with 5

$162 \mu \mathrm{L}$ of EasyLadder I DNA ladder (Bioline).

163 Samples not producing a visible band were re-amplified using template dilutions of 1:5

164 and 1:10 in water, with the thought that PCR inhibitors compounds might have been co-

165 extracted with biomineralized tissue sourced DNA, and preventing amplification.

166 Failure to observe a visible band in all PCR attempts led us to designate that particular

167 sample as unsuccessful.

168 To verify the species specificity of our mitochondrial PCRs, we tested the Perna

169 canaliculus DNA positive control template alongside DNA templates from Perna viridis

170 (Florida, USA) and Perna perna (Haga Haga, South Africa).

171

172 DNA quality assessment by PCR - gDNA: The chitin synthase (CS1) gene previously

173 identified from Mytilus galloprovincialis (Weiss et al., 2006), was used to test the tractability of

174 obtaining genomic DNA (gDNA) from our shell samples. Using genomic and transcriptomic data

175 already collected by our group for the New Zealand greenshell mussel, a homologue of the

Peer] reviewing PDF | (2019:12:44032:1:1:CHECK 21 May 2020) 
176 chitin synthase gene was identified and its sequence registered on GenBank (Benson et al.,

177 2012) with accession reference MT305043. Primers were designed to amplify a 198 bp region

178 within the coding sequence of the $P$. canaliculus chitin synthase gene sequence (Fig. 2). Our

179 analyses suggest this gene is well conserved and apparently single-copy in molluscs. PCRs

180 were performed as described earlier but without BSA, and using an annealing temperature of $18153^{\circ} \mathrm{C}$.

182 To have a sense of the availability of nuclear gDNA throughout the ageing experiment, 183 the chitin synthase PCR was tested with the $0,1^{\text {st }}, 6^{\text {th }}$ and $13^{\text {th }}$ month collections. These 184 primers were also tested in the cooked and beach-cast shell samples. Sample success 185 or failure was explored as described for the mitochondrial amplicons.

186

187 DNA quantification by qPCR - to confirm amplification of mDNA specific to our target 188 species in our extracts, qPCR was also performed in the ageing shell experiment collections at $0,1,6$ and 13 months, cooked shell experiment and on a subset of the beach-cast shell extracts. qPCR reactions $(25 \mu \mathrm{l})$ were carried out in triplicates using the

191 SensiMix SYBR Low-Rox kit (Bioline), $1 \mu$ shell extract sample and Pcan Fwd and Pcan 192 Rev primers (Table 1) (250nM final concentration). Reactions were run in a QuantStudio 1933 Real-Time PCR System (ThermoFisher Scientific), using the following program: initial 194 denaturation with $10 \mathrm{~min}$ at $95^{\circ} \mathrm{C}$, followed by 40 cycles of $15 \mathrm{sec}$. at $95^{\circ} \mathrm{C}, 15 \mathrm{sec}$. at $57^{\circ} \mathrm{C}$ and $15 \mathrm{sec}$. at $72^{\circ} \mathrm{C}$, and a melt curve cycle with $15 \mathrm{sec}$. at $95^{\circ} \mathrm{C}, 1$ minute at $60^{\circ} \mathrm{C}$ and $1 \mathrm{sec}$. at $95^{\circ} \mathrm{C}$. Data collection points were set at every annealing and elongation 197 steps of the cycling program, and at the end of the melt curve cycle. A standard dilution 198 series (undiluted DNA sample and six 1:10 serial dilutions) was made using $P$. canaliculus 199 DNA extracted from fresh mantle tissue of one individual using the DNA extraction 200 method described by (Gemmell and Akayama, 1996). DNA amount of each the standard 
201 dilution was quantified with a Qubit ${ }^{\circledR}$ 2.0 Fluorometer (ThermoFisher Scientific), using the 202 dsDNA HS Assay (ThermoFisher Scientific). All six standard dilutions, in addition to 203 undiluted $P$. canaliculus DNA sample and a negative (no template) control, were included 204 in each qPCR run as duplicates. Amplification results were visualised and acquired 205 through the ThermoFisher Connect ${ }^{\mathrm{TM}}$ software. A linear regression for the serial dilution 206 series was made for every qPCR run and used correlate amplification results with $P$. 207 canaliculus-specific DNA concentration for every sample tested. Amplification for each 208 sample was determined through its triplicate set results; any triplicate result inconsistent 209 with the other two replicates was discarded. Results with the outcomes "No amplification", 210 or "Undetermined" due to no amplification were quantified as having $0 \mathrm{ng} / \mu \mathrm{l}$ of $P$. 211 canaliculus DNA. Melting curve results for each sample were used to control for the 212 specificity of the amplified products.

213

214 DNA amplicon sequencing and sequence analysis: PCR products of samples 215 showing a visible band of expected size in agarose gels were purified using an 216 AcroPrep ${ }^{\mathrm{TM}}$ Advance filter plate (PALL) following the manufacturer's instructions.

217 Purified products were quantified with a NanoDrop 2000 spectrophotometer, and 218 sequenced using an $\mathrm{ABI} 3730 x \mathrm{~L}$ DNA Analyser (Applied Biosystems) through the 219 Genetic Analysis Services (GAS) at Otago University. Sequences were checked for taxonomic congruence using BLASTn http://blast.ncbi.nlm.nih.gov (Benson et al., 2012) and the results visualised using the BLAST Tree View function. Amplicon sequences were subsequently aligned with the Geneious software against their respective references. Sequences with poor quality (low signal, short length or failed reaction) were re-submitted to GAS, or re-amplified if they were again of poor quality. 
225 Additionally for the COX1 amplicons, all $P$. canaliculus shell sequences were also 226 aligned using MEGA version 7 (Kumar et al., 2016) together with COX1 sequences from 227 P. perna and P. viridis we obtained from our COX1 control PCR, and other published 228 COX1 sequences of representative molluscs (AB076920.1 Tridacna crocea; 229 AY260822.1 Antalis sp.; GU802411.1 Tonicella marmorea; HM431980.1 Octopus 230 rubescens;_HM862494.1 Limacina helicina; HM884239.1 Mercenaria mercenaria; 231 HM884246.1 Modiolus modiolus; JF862383.1 Margarites costalis; JF912374.1 Mytillus 232 galloprovincialis; KF643468.1 Onchidoris muricata; KF644043.1 Mytilus trossulus; 233 KF644180.1 Littorina littorea; KF644349.1 Crepidula williamsi; KM198004.1 Mytilus 234 coruscus). A phylogenetic tree was constructed using Maximum Likelihood approaches 235 with MEGA version 7 (Kumar et al., 2016) using KX121879.1 Capitella capitata (annelid) 236 as outgroup (Fig. 3).

237

\section{Results}

239 DNA extraction and quantification. Qubit measured DNA yields ranged from 0.01 to 88.4 ng DNA/ $\mu$ l (0.002 to 21.48ng DNA/mg shell) (Fig. 4), with an overall average of 13.3 $\mathrm{ng} / \mu \mathrm{l}$. In the shell ageing experiment, DNA yields were highly variable in the first collection at 0 months (Fig. 4), and included the sample with the highest yield $(88.4 \mathrm{ng} / \mu \mathrm{l}$ or 21.48

$243 \mathrm{ng} / \mathrm{mg}$ shell). Cooked shells included the sample with the lowest yield $(0.01 \mathrm{ng} / \mu \mathrm{l}$ or $2440.002 \mathrm{ng}$ DNA/ mg shell) (Fig. 4). No statistical difference between the four treatments 245 was detected when comparing Qubit measured DNA yields (one-way ANOVA, $F_{3,12}=$ $246 \quad 0.35, P=0.79$, MS Excel (2016)).

247 Beach-cast shells had on average some three-fold higher Qubit measured DNA yields 248 than cooked shells (Fig. 4). There was no significant difference (one-way ANOVA, $F_{2,21}$ 
$249=1.95, P=0.17$, MS Excel (2016)) found between the Qubit measured DNA yields from 250 each of the three locations in the shells (ventral, palial sinus and umbo regions).

251

252 DNA quality assessment by PCR. Successful PCR amplification for each primer set is 253 depicted in Table 2. A total of 168 samples were tested with each of the mitochondrial 254 primer sets. Pcan primers were used to successfully amplify, sequence and identify as $P$. 255 canaliculus $85 \%$ of the samples. The COXI primer set was successful in $91 \%$ of the 256 samples. The Chitin Synthase nuclear primer set was tested with a total of 80 samples, 257 and successfully amplified, sequenced and identified as $P$. canaliculus in $40 \%$ of these.

258 Between the three standard PCR primer sets used, a total of 416 reactions were tested, 259 and of those, $253(60.8 \%)$ were successfully amplified, sequenced and identified without 260 template dilution. Template dilution in the remaining samples was helpful to a further 76 261 reactions, but had no effect in amplification success of the remaining 87 (20.9\%). Most 262 reactions that failed amplification despite template dilution used the chitin synthase nuclear primers. A total of 46 samples could not be amplified with this primer pair. Across all three primer pairs, the majority of failed reactions (52 samples) used beach-cast shell 265 templates.

266 Elution of replicate DNA extracts in either TE buffer with low EDTA $(0.1 \mathrm{mM})$ or deionized 267 water did not improve amplification success.

268 Due to a combination of use of template in optimization trials, and evaporation in the 269 microcentrifuge tube, two individual shell samples from the $5^{\text {th }}$ month collection of the 270 aged shell experiment did not have enough template for PCR analysis with any of our 271 PCRs (Table 2).

272 Beach-cast shell samples, independently extracted in another laboratory, showed similar 273 amplification successes to our own extractions, confirming the unlikelihood of source of 274 contamination in our own research facility. 
275 PCR using the Pcan primers did not amplify with either $P$. viridis or $P$. perna templates, 276 confirming species-specificity for this assay. As expected, the COX1 PCR amplified 277 equally well in all three Perna species.

278

279 DNA quantification by qPCR - a total of 61 samples were tested with our qPCR assay 280 (Table 2), with an average yield of $0.19 \mathrm{ng} / \mu \mathrm{l}$ for both ageing shells and cooked shells, 281 and $0.02 \mathrm{ng} / \mu \mathrm{l}$ in beach-cast shells tested. Yields in ng DNA/ mg shell were 4E-04, 3E28204 and 3E-05 for each of the treatments, respectively- (Fig. 5). For every sample tested, 283 qPCR determined DNA concentration ( $\mathrm{ng} / \mathrm{t} \mu \mathrm{l})$ was lower than the corresponding Qubit 284 measured concentration. However, qPCR determined yields in the aged shells showed a 285 similar pattern of $P$. canaliculus DNA availability (Fig. 5) as the Qubit measured yields 286 (Fig. 4) in the months that were tested.

287 qPCR was able to amplify three samples that had previously failed on all attempts of 288 amplification using standard PCR with the same primers (Pcan primers) (Table 2).

289

290

DNA amplicon sequencing and sequence analysis. BLAST results for amplicon 291 sequences derived from the Pcan primer set had highest sequence similarity to GenBank 292 Accession Ref. DQ343605.1 reporting the NADH4 mitochondrial gene for $P$. canaliculus 293 (Blair et al. 2006) (average BLAST query cover (QC) and percent identity (Id) 89\% and 294 $98 \%$, respectively). COX1 amplicon sequences generally aligned as most similar to either 295 the P. canaliculus COX1 sequence with the GenBank Accession Ref. DQ343592.1 (Blair et al., 2006) (average BLAST QC 87\% and Id 98\%) or to GenBank Accession Ref. MG766134.1 (Ranjard et al., 2018), describing the $P$. canaliculus complete mitochondrion sequence (average BLAST QC $82 \%$ and Id 98\%), with overall BLAST top results of QC $29984 \%$ and Id $98 \%$. 
300 All chitin synthase amplicon sequences derived from our primers aligned solely with our

301 GenBank ref. MT305043.1 for the P. canaliculus chitin synthase gene (partial, Fig. 2), 302 with an average BLAST QC of $89 \%$ and Id of $99 \%$.

303

304 Aged shells. Mitochondrial amplification and subsequent identification by standard PCR 305 of samples was $100 \%$ successful in all individuals of all but three collections (Table 2 ).

306 Standard PCR using Pcan primers was overall slightly less successful than with using 307 COX1 primers (95.3\% amplification and identification compared to 97.7\%) (Table 2).

308 Best results for the nuclear chitin synthase primer were achieved on samples from shells 309 of freshly killed animals (month 0), and in the month 1 sampling (Table 2). The two other

310 collections tested (6 and 13 months after death) had much lower rates of identification $311(10 \%$ and $30 \%$, respectively) (Table 2$)$.

312 qPCR with Pcan primers in the ageing shell sample subset successfully amplified all but 313 one sample tested, including a sample on the 0 month collection that had not previously 314 been amplified with standard PCR using the same primers (Table 2).

315 Both ng of DNA/ mg shell tissue ratio and qPCR calculated DNA yields show a similar 316 pattern in the collections tested (months $0,1,6$ and 13), in that there was an overall 317 increase in yields from month 0 to month 1 , followed by a decrease in the following months 318 (Fig. 2 and Fig 4).

319

320 Cooked shells. $93.8 \%$ of samples were identified with each of the mitochondrial primer 321 sets, while the nuclear chitin synthase primers identified $75 \%$ of samples (Table 2 ). The 322 sample with the lowest DNA yield of cooked shells, which was also the lowest value from 323 all samples extracted for this work, failed to give results with all three amplicons with 324 standard PCR, and also in the qPCR assay (Table 2). 
325 To test our method even further, we collected and extracted replicate DNA samples from 326 shell areas that were more highly charred in two different individuals in the five minute 327 ember treatment (data not shown). There was no statistical difference detected (paired 328 T-test, $p>0.05$, MS Excel (2016)) in DNA yield values (ng DNA/ mg shell), however one 329 of the charred samples failed to amplify with any of the PCRs, despite its uncharred paired 330 replicate amplifying successfully in all of them (data not shown).

331

332 Beach-cast shells. Despite higher Qubit measured DNA yields than the cooked shells 333 (Fig. 4), this group of shell samples showed the lowest levels of successful amplification 334 and identification with standard PCR. A total of $54.2 \%$ of samples were identified with the 335 COX1 amplicon, and 25\% with the Pcan amplicon overall (Table 2). Out of the 24 samples 336 tested, only one amplified successfully and was sequenced with nuclear primers (Table 2). qPCR was successful in $55.5 \%$ of the subset of samples tested (Table 2), and calculated yields had an average of $0.02 \mathrm{ng} / \mu \mathrm{l}$ of $P$. canaliculus DNA in these samples (Fig. 5).

\section{Discussion}

342 Our results show that the carbonate shell matrix of $P$. canaliculus is a source of genetic 343 material. The DNA yield from mussel shells likely originates from shell remodeling cells

344 trapped and embedded in the matrix, which appears to provide good protection from 345 enzymatic and chemical degradation that would otherwise degrade nucleic acid 346 molecules in soft tissues. We have demonstrated that DNA can be extracted from $P$.

347 canaliculus shells whether they are fresh, aged or cooked, and subsequently applied to 348 amplify mitochondrial and nuclear regions of the genome. 
349 Our DNA extraction method (Gemmell and Akayama, 1996) avoids the use of phenol350 based solutions and extraction columns, and thus is a cheap, but effective alternative to 351 commercial kits. Provided that the sample is at least $0.5 \mathrm{~g}$ in weight, and that primer design 352 takes into account the need for short-length amplicons (Taberlet et al., 1999), our data 353 demonstrates the suitability of this method for extracting PCR-amplifiable DNA from 354 bivalve shells for up to thirteen months, and in fresh samples prepared as they would be 355 for human consumption.

356 We propose that the amount and quality of DNA that can be extracted and amplified from 357 shell material relies on a balance between fine and coarsely grounded shell tissue, and 358 shell integrity, particularly of inner shell layers. We observed that disruption of shell 359 samples of similar age showed variability of DNA yields (Fig. 4), as also observed by 360 (Geist et al., 2008) in fresh pearl mussel shells.

361 Well-weathered samples such as those from the beach-cast set had low shell integrity as 362 they were very brittle, presented areas lacking the periostracum layer, breakage, and 363 evidence of boring trematode parasites, likely due to a combination of age and 364 environmental exposure causing DNA degradation, which translated as the group of 365 samples with lowest DNA yields tested (Fig. 5). This relationship was also observed by 366 (Der Sarkissian et al., 2017) when extracting DNA from ancient shell samples. Loss of 367 the periostracum layer during cooking of fresh shells decreased DNA extraction yields, 368 but did not have an effect on DNA analysis success in this group of samples, even in 369 those collected from charred areas.

370 qPCR DNA quantification showed a similar trend in the amounts of DNA extracted

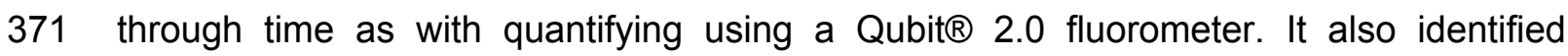
372 significant foreign DNA contamination in the beach-cast shell samples, which allied with 373 the low yields of species-specific DNA, possibly highly degraded, explains the poorest 374 amplification results of all sample groups. We were therefore not able to establish a 
375 connection between shell sample area (ventral, palial or umbo) and DNA extraction 376 success.

377 Co-extraction of PCR inhibitors from samples collected from the environment, such as 378 with forensic or ancient samples, is a well-known issue (Alaeddini, 2012). Dilution of DNA 379 extracts with DNase-free water is a common method to circumvent PCR inhibition (Kemp 380 et al., 2006), and appears to have been moderately successful in our experiment.

381 Both mitochondrial primer sets were successfully used to amplify shell extracts. As with 382 (Frantzen et al., 1998), our COX1 primers amplifying a fragment $\sim 100$ bp shorter that the 383 Pcan amplicon (Table 1), were the most successful.

384 A slightly lower amplification success with mitochondrial primers in the earliest collections 385 of the aged shell experiment (Table 2) could be linked to the presence of foreign DNA 386 from biofilm or shell parasite organisms in the sample's surface. This DNA would be expected to degrade with time, as it is not imbedded in the shell's tissue matrix.

388

389

390

391

392 393 394 395 396 397 398 399 400
The sharp drop in nuclear DNA identification success subsequent to the first month of sampling could indicate that reliable extraction and amplification of nuclear DNA from aged Perna canaliculus shell may require specialized protocols. Other studies amplifying mitochondrial and nuclear DNA from shell extracts also reported poorer results with nuclear amplicons (Barsh and Murphy, 2008, Geist et al., 2008). The disparity between mitochondrial and nuclear results is likely a reflection of higher cell copy numbers of mitochondrial DNA molecules compared to nuclear molecules and the inherent protection afforded by a circular genome. If, as suggested by (Mount et al., 2004), DNA in shells has its origin in occasionally trapped cells, the higher copy number of mitochondrial DNA molecules would enable amplification of mitochondrial sequences, but not necessarily of nuclear sequences. (Geist et al., 2008) reported $89 \%$ success genotyping fresh shells of freshwater pearl mussels with nine microsatellite markers in. Our nuclear amplification success with fresh shells in the ageing experiment was $80 \%$, which is very comparable.

Peer] reviewing PDF | (2019:12:44032:1:1:CHECK 21 May 2020) 
401 Both nuclear and mitochondrial DNA analyses are feasible in shells of bivalves prepared 402 as they would be for human consumption by exposure to high heat, possibly even from 403 charred shell regions. This is of particular significance for the analysis of shell midden 404 material, which is usually characterized by stratified deposits of consumed shelled 405 animals such as bivalve molluscs, and indicates that DNA imbedded in bivalve shell 406 matrix is well protected against degradation from high temperatures such as those used 407 for cooking food.

408 Mitochondrial DNA extraction and amplification from mollusc shells has been reported in 409 a variety of species, from fresh shells of freshwater pearl mussels (Geist et al., 2008) and 410 Pacific oyster (Wang et al., 2012), up to 50 year old snail shells (Andree and López, 2013, 411 Caldeira et al., 2004, Villanea et al., 2016), 70 year old abalone shells (Hawk, 2010) and 412 even 125 year old oyster shells (Barsh and Murphy, 2008). In fact, (Der Sarkissian et al., 413 2017) recently established that shell DNA extraction from a variety of marine mollusc 414 species aged up to 7,000 years BP is possible and can be used to retrieve not only 415 mollusc endogenous DNA, but also that of the natural microbiome, which could include 416 pathogenic organisms, symbiotic to living molluscs. It is therefore very likely that 417 mitochondrial DNA analysis can be successful in $P$. canaliculus shells for periods longer 418 than the ones tested here.

419 Our findings could be significant in a number of areas, such as genotyping of historical 420 collections, bioprospection of invasive species, and potentially shell midden research. In the 421 greenshell mussel aquaculture industry, engraving the shell of animals with an identification 422 number is a common technique (Camara and Symonds, 2014) that could be coupled with DNA 423 extraction using the shell chips produced as a way of genotyping valuable aquaculture 424 specimens, or endangered mollusc species, without the need to kill the animals.

425 Ancient shells DNA analysis techniques for shells such as those described by (Der 426 Sarkissian et al., 2017) are exciting new developments in this field, demonstrating the 
427 ability of mollusc shell matrices of entrapping and providing protection against nucleic

428 acid degradation post-mortem, potentially for thousands of years.

429 Bivalve molluscs have been widely used for coastal monitoring anthropogenic aquatic 430 contaminants such as heavy metals (Goldberg et al., 1978, Azizi et al., 2018), micro 431 plastics (Ward et al., 2019) and human pathogen transmission (Gyawali et al., 2019, 432 Razafimahefa et al., 2019) together with seasonal ecotoxicological problems such as 433 algal blooms (Gibble et al., 2016, Hinder et al., 2011). Their shells have also been used 434 for almost four decades as a proxy to determine exposure to heavy metal concentrations 435 in modern samples (Yap et al., 2002, Koide et al., 1982), historic (Wing et al., 2019) and 436 archaeological samples (Binkowski et al., 2019). Along with being a source of genetical 437 material not just of the individual itself, but pathogens and conditions that they've been exposed to makes mollusc shells a valuable resource to assess the environment in 439 present and past times.

440

\section{References}

442 ALAEDDINI, R. 2012. Forensic implications of PCR inhibition--A review. Forensic Sci Int Genet, $4436,297-305$.

444

445

ANDREE, K. B. \& LÓPEZ, M. A. 2013. Species identification from archived snail shells via 446 genetic analysis: a method for DNA extraction from empty shells. Molluscan Research, 33, 1-5.

447

448

APPELTANS, W., AHYONG, S. T., ANDERSON, G., ANGEL, M. V., ARTOIS, T., BAILLY, N., 449

BAMBER, R., BARBER, A., BARTSCH, I., BERTA, A., BLAZEWICZ-PASZKOWYCZ, M., 450 BOCK, P., BOXSHALL, G., BOYKO, C. B., BRANDAO, S. N., BRAY, R. A., BRUCE, N. L., 
452 DAHDOUH-GUEBAS, F., DAVIE, P. J., DAWSON, M. N., DE CLERCK, O., DECOCK, W., DE 453 GRAVE, S., DE VOOGD, N. J., DOMNING, D. P., EMIG, C. C., ERSEUS, C., ESCHMEYER, 454 W., FAUCHALD, K., FAUTIN, D. G., FEIST, S. W., FRANSEN, C. H., FURUYA, H., GARCIA455 AlVAREZ, O., GERKEN, S., GIBSON, D., GITTENBERGER, A., GOFAS, S., GOMEZ456 DAGLIO, L., GORDON, D. P., GUIRY, M. D., HERNANDEZ, F., HOEKSEMA, B. W., 457 HOPCROFT, R. R., JAUME, D., KIRK, P., KOEDAM, N., KOENEMANN, S., KOLB, J. B., 458 KRISTENSEN, R. M., KROH, A., LAMBERT, G., LAZARUS, D. B., LEMAITRE, R., 459 LONGSHAW, M., LOWRY, J., MACPHERSON, E., MADIN, L. P., MAH, C., MAPSTONE, G., 460 MCLAUGHLIN, P. A., MEES, J., MELAND, K., MESSiNG, C. G., MILLS, C. E., MOLODTSOVA, 461 T. N., MOOI, R., NEUHAUS, B., NG, P. K., NIELSEN, C., NORENBURG, J., OPRESKO, D. M., 462 OSAWA, M., PAUlAY, G., PERRIN, W., PILGER, J. F., POORE, G. C., PUGH, P., READ, G. 463 B., REIMER, J. D., RIUS, M., ROCHA, R. M., SAIZ-SALINAS, J. I., SCARABINO, V., 464 SCHIERWATER, B., SCHMIDT-RHAESA, A., SCHNABEL, K. E., SCHOTTE, M., 465 SCHUCHERT, P., SCHWABE, E., SEGERS, H., SELF-SULLIVAN, C., SHENKAR, N., SIEGEL, 466 V., et al. 2012. The magnitude of global marine species diversity. Curr Biol, 22, 2189-202. 467 468 469 AZIZI, G., AKODAD, M., BAGHOUR, M., LAYACHI, M. \& MOUMEN, A. 2018. The use of Mytilus spp. mussels as bioindicators of heavy metal pollution in the coastal environment. A 470 review. Journal of Materials and Environmental Sciences, 9, 1170-1181.

BALBO, A., MADELLA, M., GODINO, I. B. \& ÁLVAREZ, M. 2011. Shell midden research: An 473 interdisciplinary agenda for the Quaternary and Social Sciences. Quaternary International, 239, $474 \quad 147-152$.

\section{5}

476 BARSH, R. \& MURPHY, M. 2008. Opportunities for reconstruction of pre-Contact native oyster 477 distribution and population structure in north Puget Sound. NOAA Restoration Centre., 86 pp. 
478

479 BENSON, D. A., KARSCH-MIZRACHI, I., CLARK, K., LIPMAN, D. J., OSTELL, J. \& SAYERS, 480 E. W. 2012. GenBank. Nucleic Acids Res, 40, D48-53.

481

482 BINKOWSKI, L. J., BLASZCZYK, M., PRZYSTUPINSKA, A., OZGO, M. \& MASSANYI, P. 2019.

483 Metal concentrations in archaeological and contemporary mussel shells (Unionidae):

484 Reconstruction of past environmental conditions and the present state. Chemosphere, 228, $485 \quad 756-761$.

486

487 BLAIR, D., WAYCOTT, M., BYRNE, L., DUNSHEA, G., SMITH-KEUNE, C. \& NEIL, K. M. 2006.

488 Molecular discrimination of Perna (Mollusca: Bivalvia) species using the polymerase chain

489 reaction and species-specific mitochondrial primers. Mar Biotechnol (NY), 8, 380-5.

490

491 CALDEIRA, R. L., JANNOTTI-PASSOS, L. K., LIRA, P. M. \& CARVALHO, O. S. 2004.

492 Diagnostic of Biomphalaria Snails and Schistosoma mansoni: DNA Obtained from Traces of 493 Shell Organic Materials. Memorial Institute Oswaldo Cruz, 99, 499-502.

CAMARA, M. D. \& SYMONDS, J. E. 2014. Genetic improvement of New Zealand aquaculture 496 species: programmes, progress and prospects. New Zealand Journal of Marine and Freshwater 497 Research, 48, 466-491.

498

COLONESE, A. C., MANNINO, M. A., BAR-YOSEF MAYER, D. E., FA, D. A., FINLAYSON, J.

C., LUBELL, D. \& STINER, M. C. 2011. Marine mollusc exploitation in Mediterranean prehistory:

501 An overview. Quaternary International, 239, 86-103.

502 
503 COUTELLEC, M. A. 2017. Mollusc shells as metagenomic archives: The true treasure is the 504 chest itself. Mol Ecol Resour, 17, 854-857.

505

506 DEMARCHI, B., WILLIAMS, M. G., MILNER, N., RUSSELL, N., BAILEY, G. \& PENKMAN, K. 507 2011. Amino acid racemization dating of marine shells: A mound of possibilities. Quat Int, 239, 508 114-124.

509

510 DER SARKISSIAN, C., PICHEREAU, V., DUPONT, C., ILSOE, P. C., PERRIGAULT, M., 511 BUTLER, P., CHAUVAUD, L., EIRIKSSON, J., SCOURSE, J., PAILLARD, C. \& ORLANDO, L. 512 2017. Ancient DNA analysis identifies marine mollusc shells as new metagenomic archives of 513 the past. Mol Ecol Resour.

514

515 DOHERTY, S., GOSLING, E. \& WAS, A. 2007. Bivalve ligament- - a new source of DNA for 516 historical studies. Aquatic Biology, 1, 161-165.

517

518 ESTEVEZ, J., PIANA, E., SCHIAVINI, A. \& JUAN-MUNS, N. 2001. Archaeological Analysis of 519 Shell Middens in the Beagle Channel, Tierra del Fuego Island. International Journal of 520 Osteoarchaeology, 11, 24-33.

521

522 FLEURY, C., MARIN, F., MARIE, B., LUQUET, G., THOMAS, J., JOSSE, C., SERPENTINI, A. 523 \& LEBEL, J. M. 2008. Shell repair process in the green ormer Haliotis tuberculata: a histological 524 and microstructural study. Tissue Cell, 40, 207-18.

525

526 FRANTZEN, M. A. J., SILK, J. B., FERGUSON, J. W. H., WAYNE, R. K. \& KOHN, M. H. 1998. 527 Empirical evaluation of preservation methods for faecal DNA. Mol Ecol, 7, 1423-1428. 
529 FURUHASHI, T., SCHWARZINGER, C., MIKSIK, I., SMRZ, M. \& BERAN, A. 2009. Molluscan

530 shell evolution with review of shell calcification hypothesis. Comp Biochem Physiol B Biochem

$531 \mathrm{Mol}$ Biol, 154, 351-71.

532

533 GEIST, J., WUNDERLICH, H. \& KUEHN, R. 2008. Use of mollusc shells for DNA-based 534 molecular analyses. Journal of Molluscan Studies, 74, 337-343.

535

536 GEMMELL, N. J. \& AKAYAMA, S. 1996. An efficient method for the extraction of DNA from 537 vertebrate tissues. Trends in Genetics, 12, 338-339.

538

539 GIBBLE, C. M., PEACOCK, M. B. \& KUDELA, R. M. 2016. Evidence of freshwater algal toxins

540 in marine shellfish: Implications for human and aquatic health. Harmful Algae, 59, 59-66.

541

542 GOLDBERG, E. D., BOWEN, V. T., FARRINGTON, J. W., HARVEY, G., MARTIN, J. H., 543 PARKER, P. L., RISEBROUGH, R. W., ROBERSTON, W., SCHNEIDER, E. \& GAMBLE, E. 544 1978. The Mussel Watch. Environmental Conservation, 5.

545

546 GYAWALI, P., CROUCHER, D., AHMED, W., DEVANE, M. \& HEWITT, J. 2019. Evaluation of 547 pepper mild mottle virus as an indicator of human faecal pollution in shellfish and growing 548 waters. Water Res, 154, 370-376.

549

550 HAWK, H. 2010. Historic Genetic Diversity of the Endangered White Abalone (Haliotis

551 Sorenseni). Master of Science in Marine Science, California State University Monterey Bay.

552

553 HEBERT, P. D. \& GREGORY, T. R. 2005. The promise of DNA barcoding for taxonomy. Syst 554 Biol, 54, 852-9. 
555

556 HIGGINS, D., ROHRLACH, A. B., KAIDONIS, J., TOWNSEND, G. \& AUSTIN, J. J. 2015.

557 Differential nuclear and mitochondrial DNA preservation in post-mortem teeth with implications 558 for forensic and ancient DNA studies. PLoS One, 10, e0126935.

559

560 HINDER, S. L., HAYS, G. C., BROOKS, C. J., DAVIES, A. P., EDWARDS, M., WALNE, A. W. \&

561 GRAVENOR, M. B. 2011. Toxic marine microalgae and shellfish poisoning in the British Isles:

562 history, review of epidemiology, and future implications. Environmental Health, 10.

563

564 HÖSS, M. \& PÄÄBO, S. 1993. DNA extraction from Pleistocene bones by a silica-based

565 purification method. Nucleic Acids Research, 21, 3913-3914.

566

567 IVANINA, A. V., FALFUSHYNSKA, H. I., BENIASH, E., PIONTKIVSKA, H. \& SOKOLOVA, I. M.

568 2017. Biomineralization-related specialization of hemocytes and mantle tissues of the Pacific 569 oyster Crassostrea gigas. J Exp Biol, 220, 3209-3221.

570

571 KALMÁR, T., BACHRATI, C., MARCSIK, A. \& RASKÓ, I. 2000. A simple and efficient method 572 for PCR amplifiable DNA extraction from ancient bones. Nucleic Acids Res, 28.

573

574 KEMP, B. M., MONROE, C. \& SMITH, D. G. 2006. Repeat silica extraction: a simple technique

575 for the removal of PCR inhibitors from DNA extracts. Journal of Archaeological Science, 33, $576 \quad 1680-1689$.

577

578 KIDWELL, S. M. 2001. Preservation of Species Abundance in Marine Death Assemblages.

579 Science, 294.

580 
581 KIM, K. C. \& BYRNE, L. B. 2006. Biodiversity loss and the taxonomic bottleneck: emerging 582 biodiversity science. Ecological Research, 21, 794-810.

583

584 KOIDE, M., LEE, D. S. \& GOLDBERG, E. D. 1982. Metal and Transuranic Records in Mussel 585 Shells, Byssal Threads and Tissues. Estuarine, Coastal and Shelf Science, 15, 679-695.

586

587 KRANTZ, D. E., WILLIAMS, D. F. \& JONES, D. S. 1987. Ecological and Paleoenvironmental 588 Information Using Stable Isotope Profiles from Living and Fossil Molluscs. Palaeogeography, 589 Palaeoclimatology, Palaeoecology, 58, 249-266.

590

591 KUMAR, S., STECHER, G. \& TAMURA, K. 2016. MEGA7: Molecular Evolutionary Genetics 592 Analysis Version 7.0 for Bigger Datasets. Mol Biol Evol, 33, 1870-4.

593

594

LI, S., LIU, Y., LIU, C., HUANG, J., ZHENG, G., XIE, L. \& ZHANG, R. 2016. Hemocytes

595

participate in calcium carbonate crystal formation, transportation and shell regeneration in the

596 pearl oyster Pinctada fucata. Fish Shellfish Immunol, 51, 263-270.

597

598

MOUNT, A. S., WHEELER, A. P., PARAKDAR, R. P. \& SNIDER, D. 2004. Hemocyte-Mediated 599 Shell Mineralization in the Eastern Oyster. Science Reports, 304.

600

601 PÄÄBO, S., POINAR, H., SERRE, D., JAENICKE-DESPRES, V., HEBLER, J., ROHLAND, N., 602 KUCH, M., KRAUSE, J., VIGILANT, L. \& HOFREITER, M. 2004. Genetic analyses from ancient 603 DNA. Annu Rev Genet, 38, 645-79.

604

605 RANJARD, L., WONG, T. K. F., KÜLHEIM, C., RODRIGO, A. G., RAGG, N. L. C., PATEL, S. \& 606 DUNPHY, B. J. 2018. Complete mitochondrial genome of the green-lipped mussel, Perna 
607 canaliculus (Mollusca: Mytiloidea), from long nanopore sequencing reads. Mitochondrial DNA 608 Part B, 3, 175-176.

609

610 RAZAFIMAHEFA, R. M., LUDWIG-BEGALL, L. F. \& THIRY, E. 2019. Cockles and mussels, 611 alive, alive, oh-The role of bivalve molluscs as transmission vehicles for human norovirus 612 infections. Transbound Emerg Dis.

613

614 RHOADS, D. C. P., G. 1970. The Use of Molluscan Shell Growth Patterns in Ecology and 615 Palaeoecology. Lethaia, 3, 143-161.

616

617 ROHLAND, N. \& HOFREITER, M. 2007. Ancient DNA extraction from bones and teeth. Nat 618 Protoc, 2, 1756-62.

619

620

TABERLET, P., WAITS, L. P. \& LUIKART, G. 1999. Noninvasive genetic sampling: look before 621 you leap. Tree-Perspectives, 14.

622

623 TAUTZ, D., ARCTANDER, P., MinELLI, A., H., T. R. \& VOGLER, A. P. 2003. A plea for DNA 624 taxonomy. Trends in Ecology and Evolution, 18, 70-75.

625

626

UNTERGASSER, A., CUTCUTACHE, I., KORESSAAR, T., YE, J., FAIRCLOTH, B. C., REMM, 627 M. \& ROZEN, S. G. 2012. Primer3--new capabilities and interfaces. Nucleic Acids Res, 40, $628 \mathrm{e} 115$.

629

630 VENDRASCO, M. J., RODRÍGUEZ-NAVARRO, A. B., CHECA, A. G., DEVAERE, L. \& 631 PORTER, S. M. 2016. To Infer the early Evolution of Mollusc Shell Microstructures. Key 632 Engineering Materials, 672, 113-133. 
633

634 VILLANEA, F. A., PARENT, C. E. \& KEMP, B. M. 2016. Reviving Galápagos snails: ancient

635 DNA extraction and amplification from shells of probably extinct endemic land snails. Journal of 636 Molluscan Studies, 82, 449-456.

637

638 WANG, X., SONG, X., LI, L. \& ZHANG, G. 2012. An improved Method of DNA Extraction from 639 the Shell of the Pacific Oyster, Crassostrea gigas. The Israeli Journal of Aquaculture, 4.

640

641 WARD, J. E., ROSA, M. \& SHUMWAY, S. E. 2019. Capture, ingestion, and egestion of

642 microplastics by suspension-feeding bivalves: a 40-year history. Anthropocene Coasts, 2, 39-

64349.

644

645 WEISS, I. M., SCHONITZER, V., EICHNER, N. \& SUMPER, M. 2006. The chitin synthase 646 involved in marine bivalve mollusk shell formation contains a myosin domain. FEBS Lett, 580, $647 \quad 1846-52$.

648

649

WING, S. R., O'CONNELL-MILNE, S. A., WING, L. C. \& REID, M. R. 2019. Trace metals in 650 Antarctic clam shells record the chemical dynamics of changing sea ice conditions. Limnology and Oceanography.

652

653 YAP, C. K., ISMAIL, A., TAN, S. G. \& ABDUL RAHIM, I. 2002. Can the shell of the green-lipped 654 mussel Perna viridis from the west coast of Peninsular Malaysia be a potential biomonitoring 655 material for $\mathrm{Cd}, \mathrm{Pb}$ and $\mathrm{Zn}$ ? Estuarine, Coastal and Shelf Science, 57, 623-630. 
657 ZANDEN, M. J. V. \& RASMUSSEN, J. B. 2001. Variation in $\delta 15 N$ and $\delta 13 N$ trophic

658 fractionation: Implications for aquatic food web studies. Limnology and Oceanography, 46, $659 \quad 2061-2066$.

660 


\section{Table 1 (on next page)}

Primers used to assess DNA quality from shell tissue extracts 


\begin{tabular}{|c|c|c|c|}
\hline Primer & Sequence & Amplicon (bp) & Target Region \\
\hline Pcan Fwd & ACAGACTTCACTTATACACAACAAC & \multirow{2}{*}{305} & \multirow{2}{*}{ NADH4 - ATP8 gene region } \\
\hline Pcan Rev & AGGGCTCTAACTCAATATAACCCC & & \\
\hline COXI Fwd* & GRGATCCTGTTTTATTTCAGCAYGT & \multirow[b]{2}{*}{191} & \multirow[b]{2}{*}{ cox1 gene } \\
\hline COXI Rev & TGCCCAAACAACACACCCTA & & \\
\hline Chitin S.Fwd & CCGTGTCTGTAATGTTGGTCTA & \multirow[b]{2}{*}{198} & \multirow[b]{2}{*}{ Chitin Synthase nuclear gene } \\
\hline Chitin S. Rev & TCTTTGCCATTCGTTCACAC & & \\
\hline *Similar to $\mathrm{pr}$ & ernacox1F used by (Blair et al., 200 & $=$ & \\
\hline
\end{tabular}

Table 1: Primers used to assess DNA quality from shell tissue extracts 


\section{Table 2 (on next page)}

Samples successfully identified as $P$. canaliculus in each experiment.

Numbers in parenthesis relate to number of samples tested, and are followed by the number of samples that were successfully amplified. 


\begin{tabular}{|c|c|c|c|c|c|c|}
\hline & \multirow{2}{*}{\multicolumn{3}{|c|}{ Mitochondrial Amplicons }} & \multirow{3}{*}{$\begin{array}{c}\text { Nuclear Amplicon } \\
\text { Chitin Synthase } \\
\text { (198 bp) }\end{array}$} \\
\hline & & & & & & \\
\hline \multirow{15}{*}{ Aged shells } & \multicolumn{2}{|c|}{ Collection (month) } & $\begin{array}{c}\text { Pcan } \\
\text { (305 bp) }\end{array}$ & $\begin{array}{c}\text { qPCR Pcan } \\
\text { (305 bp) }\end{array}$ & $\begin{array}{c}\text { COX1 } \\
\text { (191 bp) }\end{array}$ & \\
\hline & \multicolumn{2}{|c|}{$0(n=10)$} & 8 & $(n=10) 9$ & 9 & 8 \\
\hline & \multicolumn{2}{|c|}{$1(n=10)$} & 10 & $(n=9) 9$ & 10 & 7 \\
\hline & \multicolumn{2}{|c|}{$2(n=10)$} & 9 & & 9 & - \\
\hline & \multicolumn{2}{|c|}{$4(n=10)$} & 7 & & 9 & - \\
\hline & \multicolumn{2}{|c|}{$5(n=8)$} & 8 & & 8 & - \\
\hline & \multicolumn{2}{|c|}{$6(n=10)$} & 10 & $(n=9) 9$ & 10 & 1 \\
\hline & \multicolumn{2}{|c|}{$7(n=10)$} & 10 & & 10 & - \\
\hline & \multicolumn{2}{|l|}{$8(n=10)$} & 10 & & 10 & - \\
\hline & \multicolumn{2}{|c|}{$9(n=10)$} & 10 & & 10 & - \\
\hline & \multicolumn{2}{|c|}{$10(n=10)$} & 10 & & 10 & - \\
\hline & \multicolumn{2}{|c|}{$11(n=10)$} & 10 & & 10 & - \\
\hline & \multicolumn{2}{|c|}{$12(n=10)$} & 10 & & 10 & - \\
\hline & \multicolumn{2}{|c|}{$13(n=10)$} & 10 & $(n=8) 8$ & 10 & 3 \\
\hline & & $\mathrm{N}$ total $=128$ & Average $=95.3 \%$ & Average $=97.2 \%$ & Average $=97.7 \%$ & Average $=47.5 \%$ \\
\hline \multirow{6}{*}{ Cooked shells } & \multicolumn{2}{|c|}{ Treatment } & $\begin{array}{c}\text { Pcan } \\
\text { (305 bp) }\end{array}$ & $\begin{array}{l}\text { qPCR Pcan } \\
\text { (305 bp) }\end{array}$ & $\begin{array}{c}\text { COX1 } \\
(191 \mathrm{bp})\end{array}$ & $\begin{array}{c}\text { Chitin Synthase } \\
\text { (198 bp) }\end{array}$ \\
\hline & \multirow{2}{*}{ Steam } & $5 \min (n=4)$ & 4 & 4 & 4 & 3 \\
\hline & & $10 \min (n=4)$ & 3 & $(n=4) 3$ & 3 & 3 \\
\hline & \multirow{2}{*}{ Embers } & $5 \min (n=4)$ & 4 & 4 & 4 & 3 \\
\hline & & $10 \min (n=4)$ & 4 & 4 & 4 & 3 \\
\hline & \multicolumn{2}{|r|}{ Average } & $93.75 \%$ & $93.75 \%$ & $93.75 \%$ & $75 \%$ \\
\hline \multirow{5}{*}{ Beach-cast Shells } & & | region & $\begin{array}{c}\text { Pcan } \\
\text { (305 bp) }\end{array}$ & $\begin{array}{l}\text { qPCR Pcan } \\
\text { (305 bp) }\end{array}$ & $\begin{array}{c}\text { COX1 } \\
(191 \text { bp) }\end{array}$ & $\begin{array}{l}\text { Chitin Synthase } \\
\text { (198 bp) }\end{array}$ \\
\hline & Ventral ( $r$ & & 2 & $(n=4) 3$ & 3 & 1 \\
\hline & Palial sinc & $\mathrm{n}=11)$ & 2 & $(n=2) 0$ & 7 & 0 \\
\hline & Umbo (n & & 2 & $(n=3) 2$ & 3 & 0 \\
\hline & & Average & $25 \%$ & $55.5 \%$ & $54.2 \%$ & $4.2 \%$ \\
\hline
\end{tabular}

Table 2 - Samples successfully identified as $P$. canaliculus in each experiment. Numbers in parenthesis relate to number of samples tested, and are followed by the number of samples that were successfully amplified. 
Figure 1

P. canaliculus snell regions sampled in the beach-cast valves.

1) ventral region; 2) pallial sinus; 3) umbo. Image credit: Sara Ferreira.

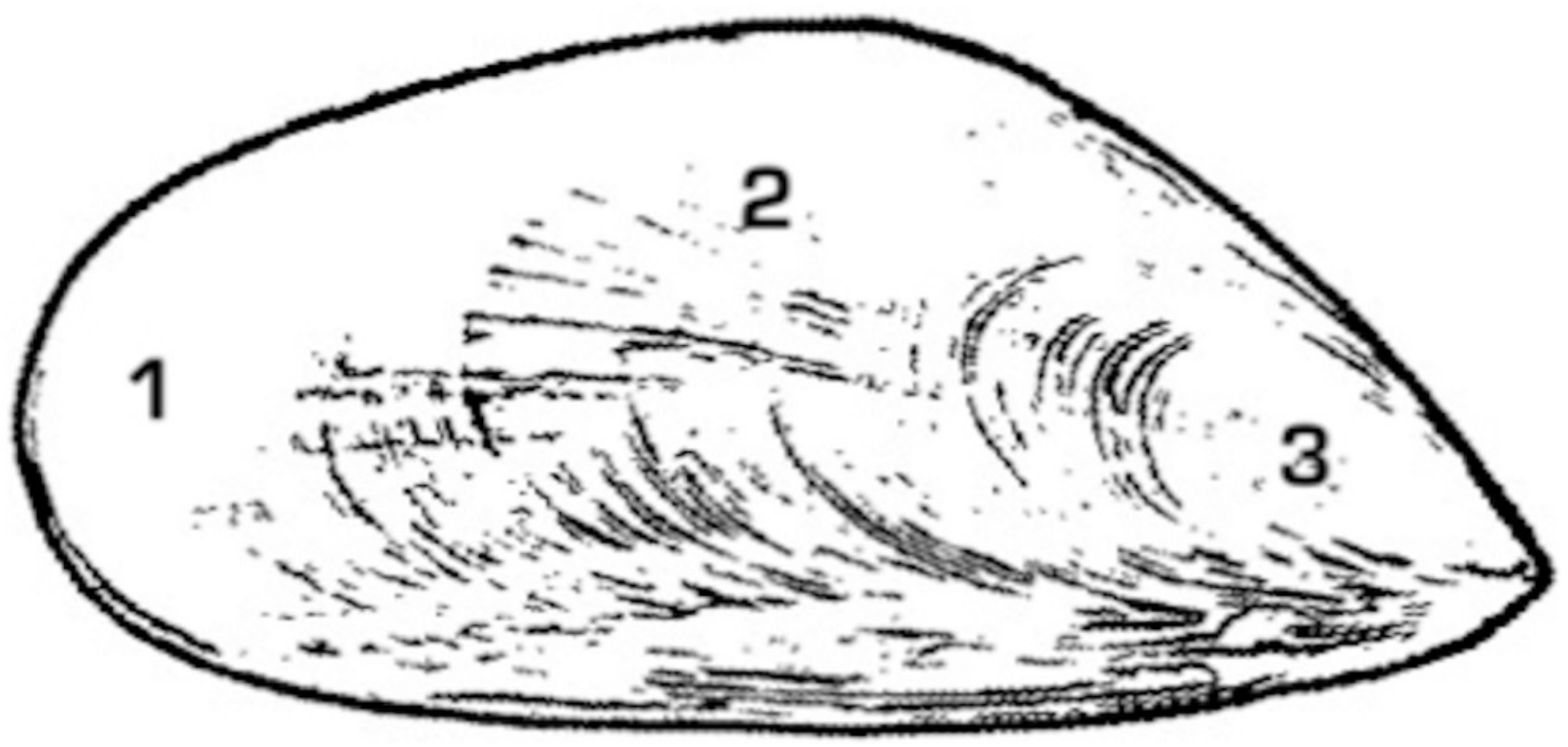


Figure 2

Alignment of the chitin synthase gene in Perna canaliculus (Ashby et al., unpublished) and Mytilus galloprovincialis (Benson et al., 2012) (GenBank Accession Ref.: EF535882.1).

Primer sequences highlighted in grey, base differences between $P$. canaliculus and $M$. galloprovincialis in red. 


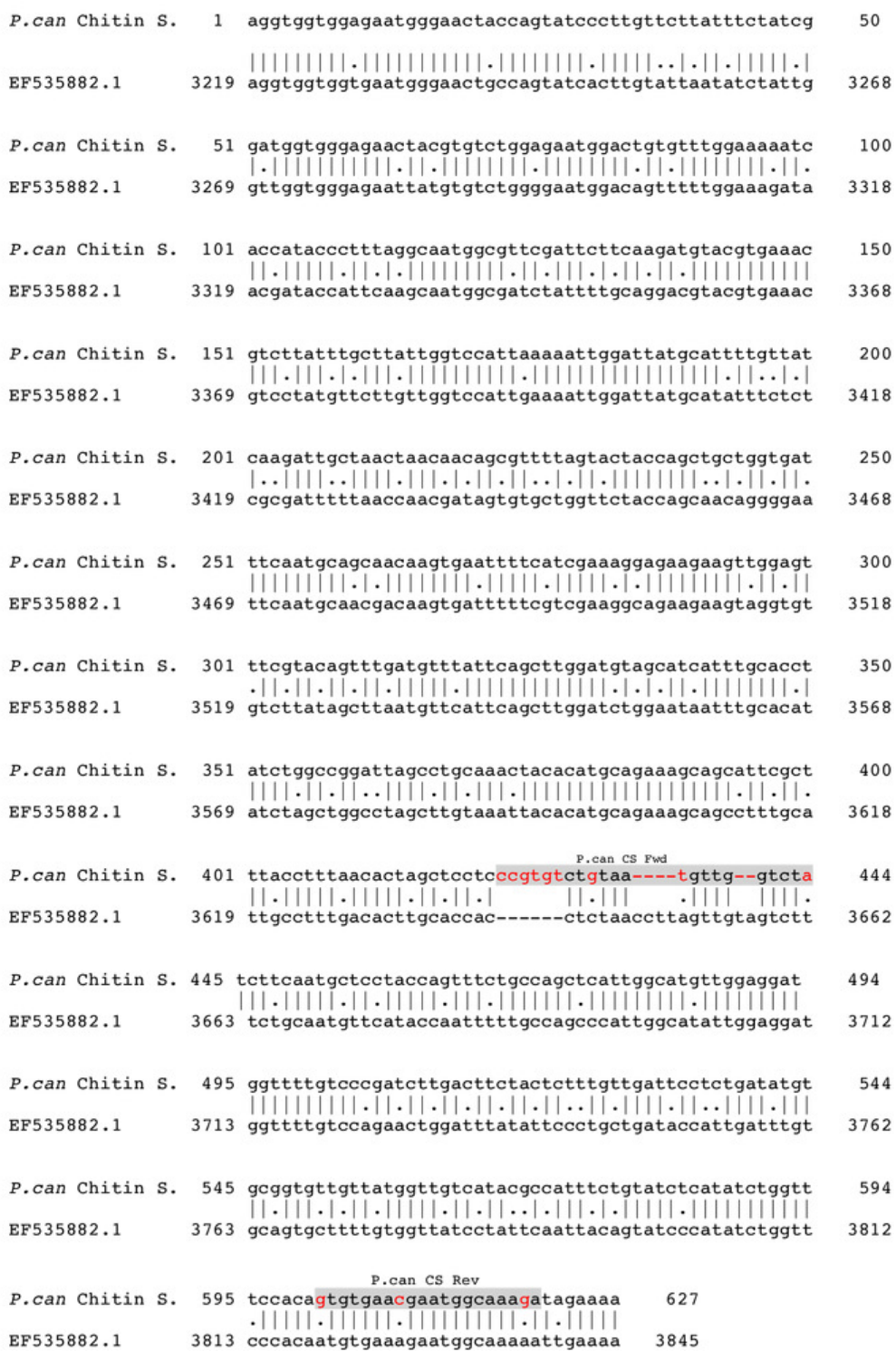

Figure 2: Alignment of the chitin synthase gene in Perna canaliculus (Ashby et al., unpublished) and Mytilus galloprovincialis (Benson et al., 2012)(GenBank Accession Ref.: EF535882.1). Primer sequences highlighted in grey, base differences between $P$. canaliculus and $M$. galloprovincialis in red. 


\section{Figure 3}

Molecular phylogenetic analysis of $P$. canaliculus COX1 shell sequences and positive control sequence, together with other COX1 mollusc species sequences.

Maximum Likelihood method based on the Tamura-Nei model [1]. Sequence KX121879.1

Capitella capitata selected as outgroup. The tree with the highest log likelihood (-1371.62) is shown. The percentage of trees in which the associated taxa clustered together is shown next to the branches. Initial tree(s) for the heuristic search were obtained automatically by applying Neighbour-Join and BioNJ algorithms to a matrix of pairwise distances estimated using the Maximum Composite Likelihood (MCL) approach, and then selecting the topology with superior log likelihood value. The tree is drawn to scale, with branch lengths measured in the number of substitutions per site. The analysis involved a total of 130 nucleotide sequences. Codon positions included were $1 s t+2 n d+3 r d+$ Noncoding. All positions containing gaps and missing data were eliminated. There was a total of 110 positions in the final dataset. Evolutionary analyses were conducted in MEGA7 [2]. 1. TAMURA, K \& NEI, M. 1993. Estimation of the number of nucleotide substitutions in the control region of mitochondrial DNA in humans and chimpanzees. Mol Biol Evol 10:512-526. 2. KUMAR, S., STECHER, G. \& TAMURA, K. 2016. MEGA7: Molecular Evolutionary Genetics Analysis Version 7.0 for Bigger Datasets. Mol Biol Evol, 33, 1870-4. 


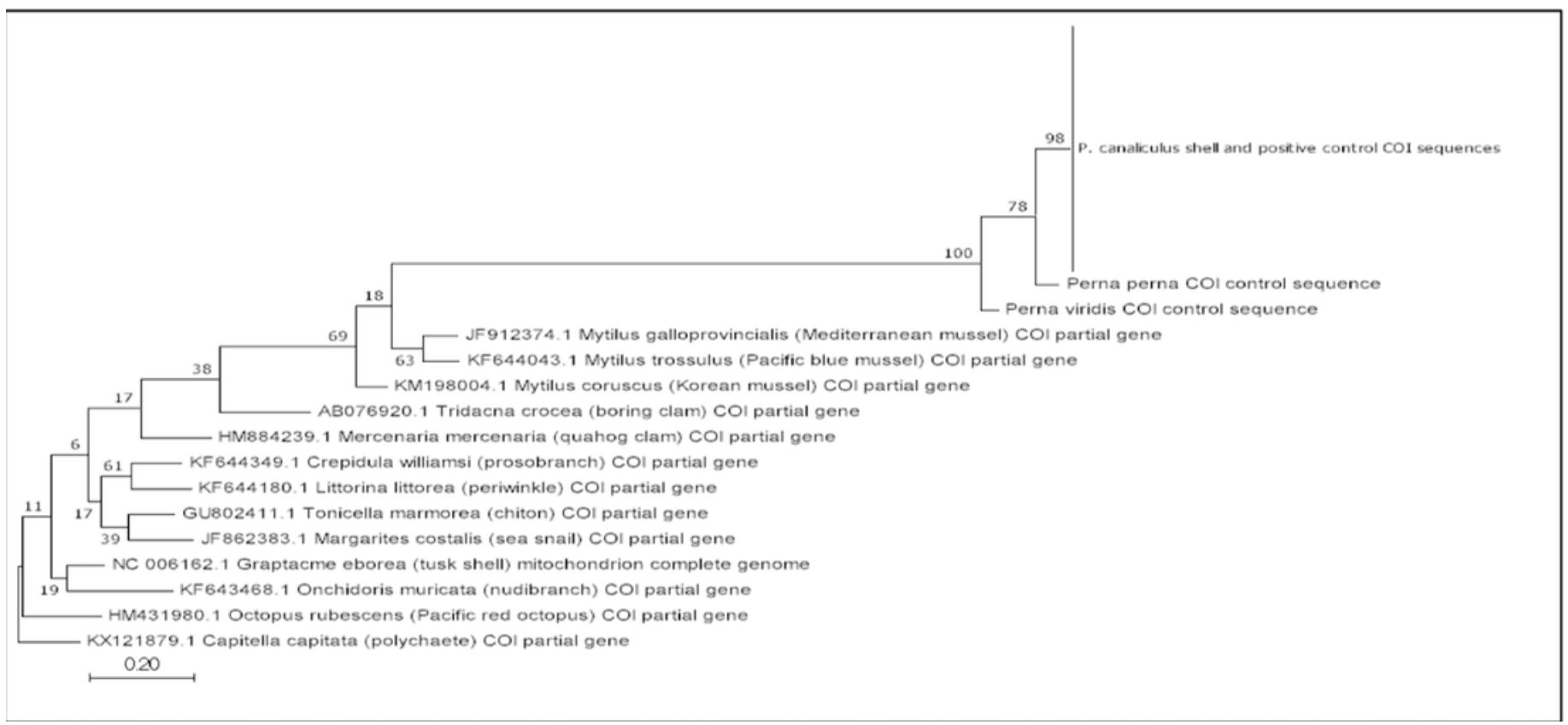


Figure 4

BoxPlot of average DNA yields.

Yields as ng DNA/mg shell weight ratio. Values through time in shell ageing experiment, and total average DNA yields from cooked and beach-cast shells (black filled box plot samples).

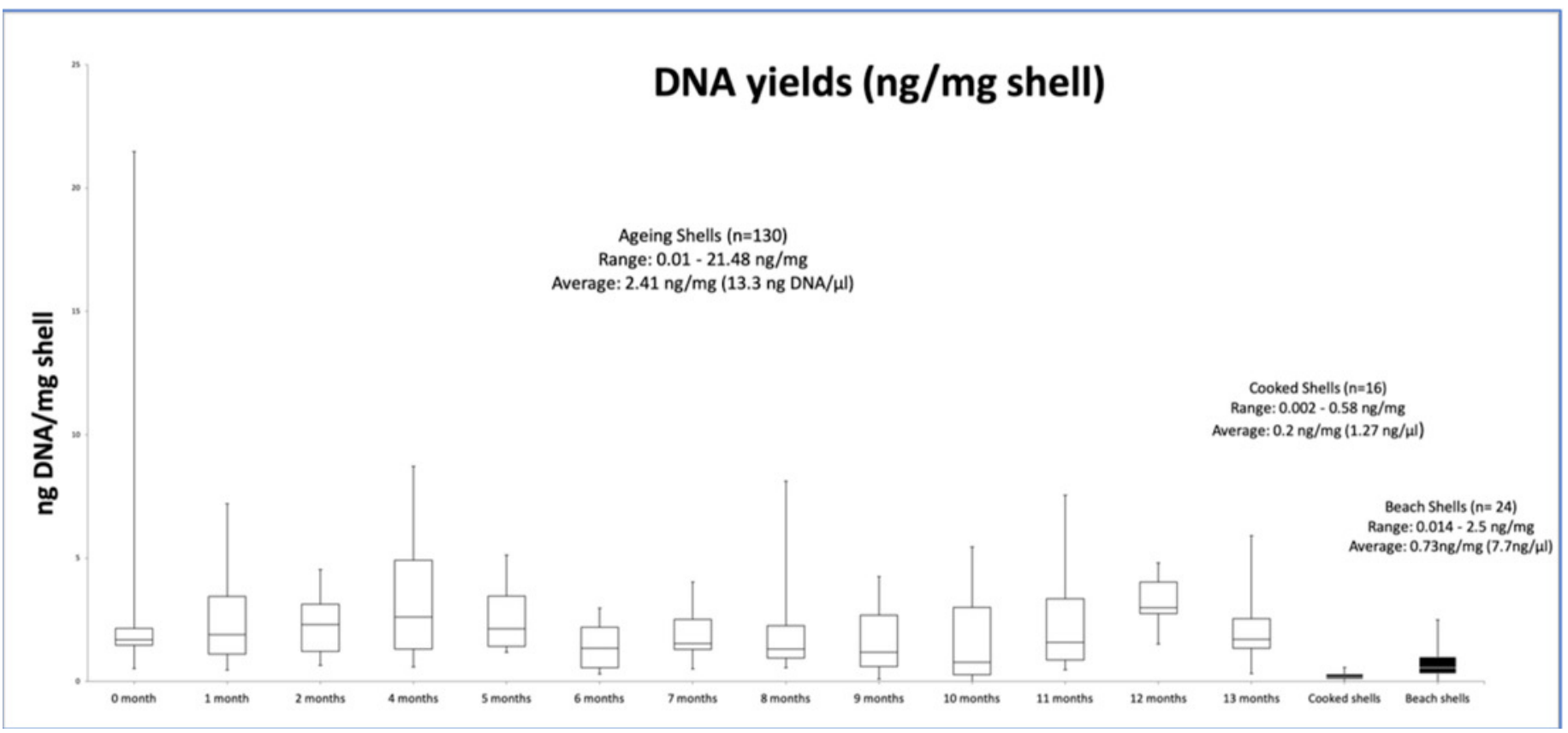


Figure 5

BoxPlot of DNA yields $(\mathrm{ng} / \mathrm{\mu l})$ determined by qPCR.

Showing the selected samples from the shell ageing, cooked shells and beach-cast shell collections

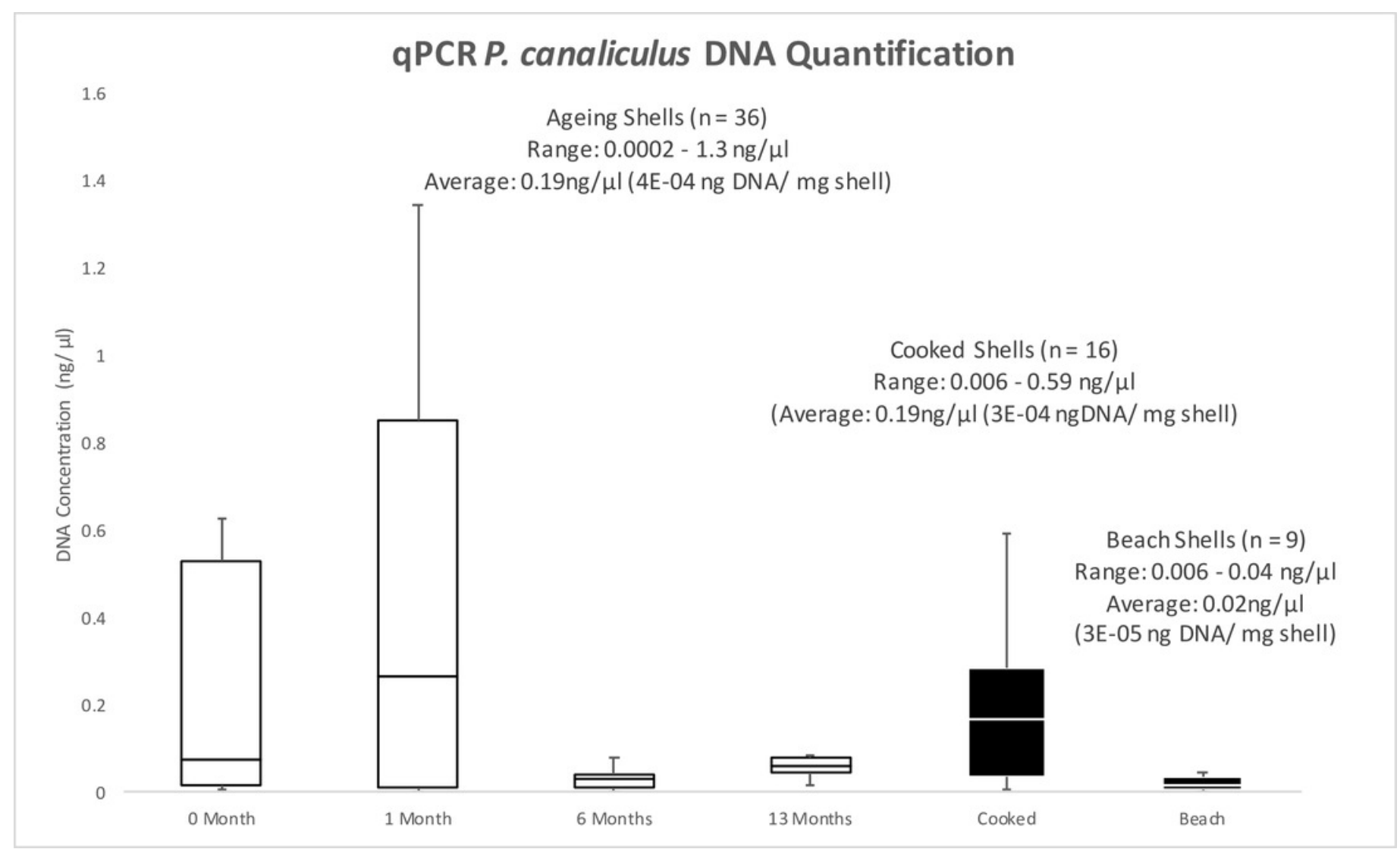

